\title{
Author Correction: DNA methylation predicts age and provides insight into exceptional longevity of bats
}

Gerald S. Wilkinson (D), Danielle M. Adams, Amin Haghani, Ake T. Lu (D), Joseph Zoller (D), Charles E. Breeze (D), Bryan D. Arnold (D), Hope C. Ball, Gerald G. Carter, Lisa Noelle Cooper (D), Dina K. N. Dechmann (D), Paolo Devanna, Nicolas J. Fasel (10, Alexander V. Galazyuk, Linus Günther, Edward Hurme (D), Gareth Jones (1), Mirjam Knörnschild, Ella Z. Lattenkamp (1D, Caesar Z. Li(D), Frieder Mayer, Josephine A. Reinhardt(1), Rodrigo A. Medellin (1), Martina Nagy (1), Brian Pope (D), Megan L. Power (1), Roger D. Ransome (D),

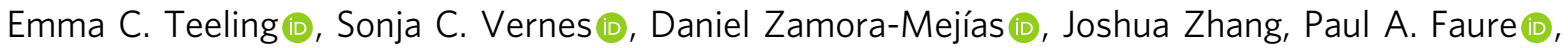
Lucas J. Greville (1D, Steve Horvath (1), L. Gerardo Herrera M. \& José J. Flores-Martínez

Correction to: Nature Communications https://doi.org/10.1038/s41467-021-21900-2, published online 12 March 2021.

The original version of this Article omitted from the author list the 34th author L. Gerardo Herrera M., who is from the 'Estación de Biología de Chamela, Instituto de Biología, Universidad Nacional Autónoma de México, 48980 San Patricio, Mexico’ and the 35th author José J. Flores-Martínez, who is from the 'Departamento de Zoología, Instituto de Biología, Universidad Nacional Autónoma de México, 04510 Ciudad de México, Mexico'. Additionally, the following was added to the Author Contributions: 'L.G.H.M., J.J.F.M., M. N., B.P., M.L.P., R.D.R., E.C.T., S.C.V., G.S.W., and D.Z. provided or prepared samples' in place of 'M.N., B.P., M.L.P., R.D.R., E.C.T., S. C.V., G.S.W., and D.Z. provided or prepared samples.'

The original version of the Supplementary Information associated with this Article contained an error in p. 4, which incorrectly read 'Bat capture and handling were conducted under permits \#7668-15 and 2492-17 from Dirección General de Vida Silvestre, and permits \#17-16 and 21-17 from Secretaría de Gobernación.' The correct version states '\#7668-15, 2492-17 and 5409-18' in place of '\#7668-15, 2492-17' and '\#17-16, 21-17 and 20-18' in place of '\#17-16 and 21-17.' The HTML has been updated to include a corrected version of the Supplementary Information.

The original version of this Article contained an error in the email address of the corresponding author Steve Horvath, which was missing the terminal edu and should be shorvath@mednet.ucla.edu

These have been corrected in both the PDF and HTML versions of the Article.

Published online: 05 May 2021

\section{Additional information}

Supplementary information The online version contains supplementary material available at https://doi.org/10.1038/s41467-021-23129-5. 
(c) (i) Open Access This article is licensed under a Creative Commons Attribution 4.0 International License, which permits use, sharing, adaptation, distribution and reproduction in any medium or format, as long as you give appropriate credit to the original author(s) and the source, provide a link to the Creative Commons license, and indicate if changes were made. The images or other third party material in this article are included in the article's Creative Commons license, unless indicated otherwise in a credit line to the material. If material is not included in the article's Creative Commons license and your intended use is not permitted by statutory regulation or exceeds the permitted use, you will need to obtain permission directly from the copyright holder. To view a copy of this license, visit http://creativecommons.org/licenses/by/4.0/.

(C) The Author(s) 2021 